\title{
Rhizosphere Mushrooms: Antagonistic Exploration of rhizospere mushrooms in Shallot (Allium ascolonicum L) specific location of Enrekang Regency
}

Hikmahwati*, Fitrianti, Harli A. Karim

Department of Agrotechnology, Faculty of Agriculture, Universitas Al Asyariah Mandar, Polewali Mandar, Indonesia

\begin{abstract}
Article Info

Volume 8, Issue 6

Page Number : 428-433

Publication Issue

November-December-2021

Article History

Accepted : 05 Dec 2021

Published : 16 Dec 2021

Enrekang Regency is one of the largest onion plant centers in south Sulawesi with an onion harvest area of 7,605 Ha. The main disease that attacks onions in Enrekang district is stem base foul disease or moler disease caused by fusarium oxysporum f.sp.cepae (FOCe). Control can be done by using biocontrol obtained from rhizosphere mushrooms in general antagonistic and can make microenvironment conditions in the soil not suitable for pathogen growth. Exploration of the ability of rhizosphere mushroom antagonists is carried out by dual culture testing method in vitro between Fusarium oxysporum and rhizosphere mushrooms. Exploration of the antagonistic ability of rhizosphere mushrooms is carried out by dual culture testing method in vitro between Fusarium oxysporum and rhizosphere mushrooms. The test results of all isolates obtained the largest average inhibition value is $74.79 \%$ in isolate number $16,73.19 \%$ in isolate number 5 and $63.16 \%$ in isolat number 6 , the lowest inhibitory value is no. $1.56 \%$, isolat no. 12 has and inhibition values range $50-56 \%$, found in isolates no. 3,7,9,13 and 14 .
\end{abstract}

Keywords: Rhizosphere mushrooms, Antagonis, Fusarium oxysporum

\section{INTRODUCTION}

Enrekang Regency is one of the largest Shallot centers in south Sulawesi with an shallot harvest area of 7,605 Ha [1] and spread in several districts. Anggeraja district with an area of 5,260 Ha, Baraka district has an area of 960 ha and Baroko district $26 \mathrm{Ha}$ [1].
Important disease that attacks onions in Enrekang district is stem root rot or moler disease caused by Fusarium oxysporum f.sp. cepae (FOCe) with an attack intensity of $72 \%-83.33 \%$ in susceptible varieties [2],[3] anthracnose disease caused by Colletotrichum sp. [4]with a disease severity of up to 64\% [5] and Trotol disease caused by Alternaria porri [6]. 
F. oxysporum is a fungus that usually causes vascular withering symptoms. The majority of vascular withering isolates are specific strains that only infect a small number of differentiated host plants based on pathogenity as a special formae, this causes this mushroom called important diseases and have an economic impact [7]. Early symptoms are seen at 14 days of age after inoculation in all varieties of onions where the leaves do not grow upright but twist, the pseudo stem grows longer, the color of the leaves pale green or yellowish and slightly withered [3].

Control that can be used is the provision of organic materials that can suppress moler disease in onions. It is reported that blotong organic matter, merang mushroom waste, straw compost and chicken manure fertilizer can suppress moler disease in shallot by $50.5 \%-63.2 \%$. This is due to the presence of microbes that are antagonistic to pathogens in organic matter that also affect the high growth of plants, the number of wet bulb weight leaves and the weight of dry bulbs [8].

Control of F. Oxysporum can also be done by increasing the durability of plants through the administration of salicylic acid invitro culture. Test results showed that the administration of exogenous salicylic acid $2.5 \mathrm{ppm}, 5 \mathrm{ppm}$, and $7.5 \mathrm{ppm}$ provided an onion resistance inducing effect [9].

Control with botanical pesticides is also effective to suppress FOCe, one of which is by using late flowers with inhibition of $47.11 \%$, at a concentration of $2.4 \%$ [10]. The use of resistant varieties can also suppress the intensity of moler disease attacks, in the cultivars of Batu ijo from Batu regency showed that this cultivar is somewhat resistant to FOCe with the intensity of the disease where the rate of infection and incubation period is slow, the number of leaves, wet weight and dry weight are high [3]. Physical Treatment with hot water immersion is also effective against inhibition of FOCe, such as immersion in
Yellow cultivars and Crok cultivars with 500C hot water for 15 minutes, Trisula cultivars with $45^{\circ} \mathrm{C}$ hot water immersion for 15 minutes [11].

The use of environmentally friendly biocontrol agency can also be used to control disease. Biocontrol as a controlling agent made from resistance-inducing soil bacteria indicates inhibition of F. oxysporum [12]. Biocontrol can be isolated from the rizosphere around plant rooting including rizosfer mushrooms.

Rhizospere mushrooms are mushrooms obtained from rhizosphere soils that are around plant root, are generally antagonistic and can make micro environment conditions in the soil unsuitable for pathogenic growth, so that their ability to infect plants decreases and Xiong et al. [13] said that rhizosphere microorganism affect plant growth and development, nitrogen uptake and utilization, and ecological adaptability.

Fabricated mushrooms can secrete secondary metabolites that are toxic to pathogens, have properties as mycoparasite that can cause lysis in pathogenic hyphae, causing competition in the fight for nutrients can also be a cause of decreased rate of pathogen infection [14].

Among rizosfer mushrooms there is a group of mushrooms that are able to stimulate plant growth then called Plant Growth Promoting Fungi (PGPF) and are able to act as antagonists that can suppress the growth of plant pathogens. Rizospheric microbes collected from bamboo, onion, grape, and guava soils showed antagonistic effectiveness in the pathogens $\mathrm{F}$. oxysporum and Rhizoctonia solani with an inhibitory percentage of 52.96 - 92.59\% [15]. Rizosfer mushroom isolates in onion plants are reported to have the ability to suppress the growth of pathogenic FOCe in-vitro with an inhibitory percentage between $65.58-84.71 \%$ and can trigger germination of onion 
seeds by isolates of the genus Aspergillus and Paecilomyces [10] (Adhi \& Suganda, 2020).

\section{METHODS AND MATERIAL}

\section{Sampling of Rhizospere Mushrooms in the Field}

Rhizosphere mushroom isolates used are 20 isolates (Tabel), are the result of rhizosphere soil isolation in healthy soils in onion production centers in Aggeraja, Baraka nad Baroko distric of Enrekang Regency, South Sulawesi. The pathogenic mushroom used is Fusarium oxysporum is a private collection that is the result of isolation from onion plants affected by moler disease in Enrekang Regency.

\section{Medium Growing Preparation}

The growing medium used is Potato Dextrose Agar (PDA) made from a mixture of $200 \mathrm{~g}$ potatoes, $20 \mathrm{~g}$ of granulated sugar, $16 \mathrm{~g}$ agar flour, 1,000 $\mathrm{ml}$ aquades and Streptomycin sulfate as a bacterial antibiotic contaminant.

\section{Antagonist Test}

The test was conducted by dual culture method between Fusarium oxysporum mushrooms from Enrekang derived from the previous research collection taken with a diameter of $1 \mathrm{~cm}$ in place $3 \mathrm{~cm}$ dr edge petri dish ( $9 \mathrm{~cm}$ in diameter) and rhizospheric mushrooms placed in the same cup with a distance of $3 \mathrm{~cm}$, made 3 repeats, then incuseded with a temperature of 280C for 5 days. Observations are made every day and the presentation of inhibition of mushroom growth is calculated by the following formula:

Percentage of inhibitory areas $=\frac{r 1-r 2}{r 1} \times 100 \%$ Where:

r1 = Radius of the colony F. oxysporum in the opposite direction to the rhizosphere mushroom

r2 = Radius of the colony F. oxysporum heading towards the rhizosphere mushroom

\section{RESULTS AND DISCUSSION}

Based on the results of in vitro dual culture antagonist testing on PDA media conducted on rizosefer mushrooms from onion plants in Enrekang Regency with pathogenic mushroom Fusarium oxysporum causing moler disease in onion plants from Enrekang regency [2] showed inhibition of pathogenic mushroom Fusarium oxysporum (Figure 1.) Observations were made from 4 DAI to $7 \mathrm{DAI}$ and 10 DAI, during which pathogenic mushrooms at control began to cover all media surfaces.

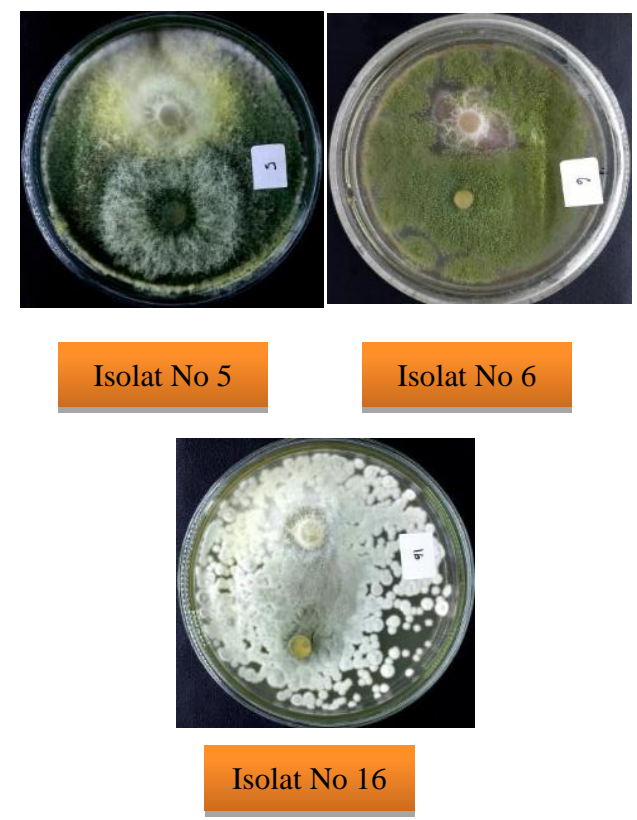

Figure 1 : Inhibition of rizosphere mushrooms in the pathogen F. oxysporum on $10 \mathrm{DAI}$

Based on the results of observations there are 18 isolates that show understanding and 2 isolates do not show the existence of inhibition. The form of inhibition is characterized by the presence of mutual inhibition areas at the meeting of 2 mushrooms. According to Ida \& Karim [16] the anatagonis isolated ability is indicated by the presence of a bland zone formed in both mushroom colonies.

Based on the average results of inhibition (Figure 2) obtained the largest value is $74.79 \%$ in isolate 
number 16 and 73.19\% in isolate number 5 and 63.16\% Supriyadi \& Yulia (2020)reported from eleven in isolat number 6 and found in isolate number 12 has the lowest inhibitory value of number $1.56 \%$, and in isolate numbers $3,7,9,13$ and 14 has a drag in the range of $50-56 \%$, then in isolates 18 and 20 found no inhibition in pathogens. This indicates the presence of rhizosphere mushrooms in pathogens . Nugroho rhizosphere isolates on onion farming in vitro is antagonistic to FOCe with inhibition of $65.58 \%$ to 84.71. Antagonism tests between Trichoderma virens G1006 and Bacillus velezensis Bs006 to Fusarium wilt of cape gooseberry disease showed inhibition severity by $71 \%$ ( García, Almario, Cotes, \& Moreno, 2020)

[14] reported that there was a $45 \%$ inhibition of FOCe growth by rizosfer mushrooms. Suganda, Simarmata,

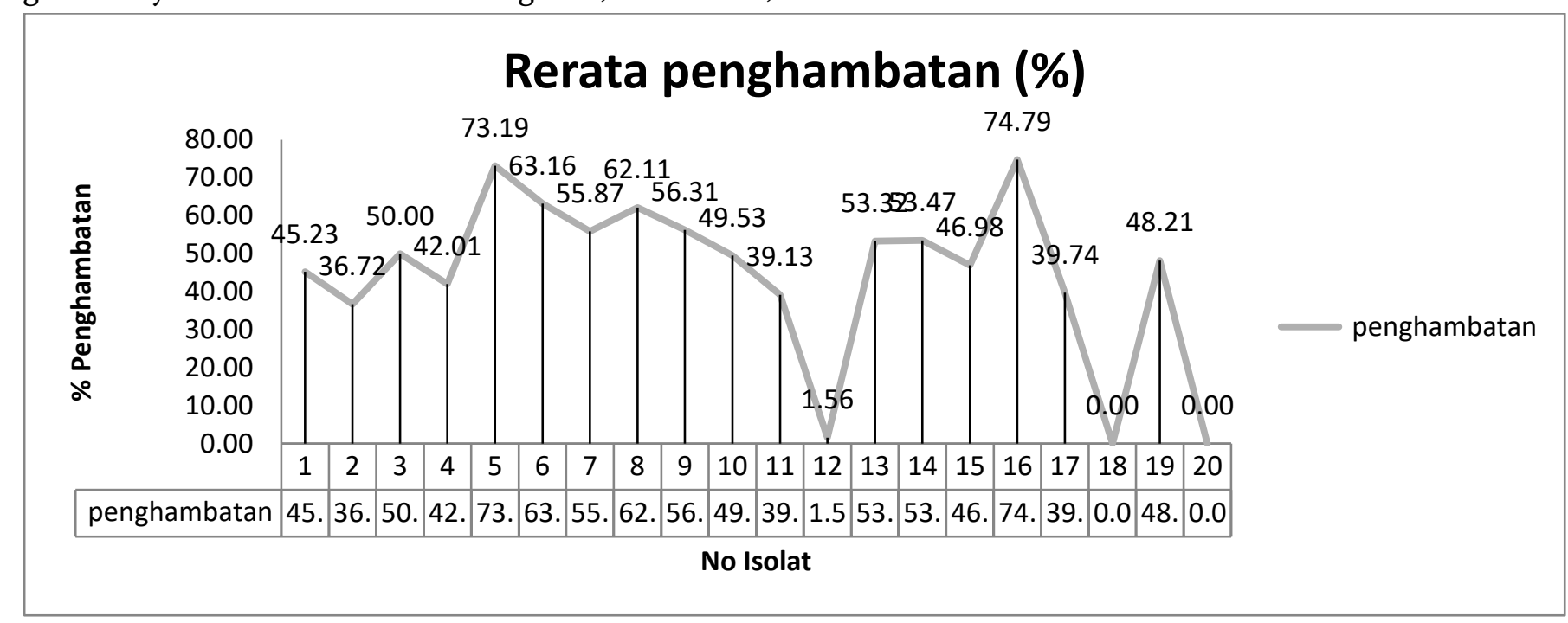

Figure 2: Average inhibition in Fusarium oxysporum mushrooms by rizosfer mushrooms

The average value of inhibition is determined by different factors that affect the ability of isolates to suppress the growth of pathogenic mushrooms. Several factors include the ability of the isolate to produce hydrolytic enzymes, the number of enzymes produced, the breed life of mushrooms, the composition of the medium and the incubation time [16], competition of growing space and nutrition [18]. [19] Suganda, et al., reported rhizospheric mushrooms of the genus Aspergillus cause lysis and melanisation in FOCe, genus Penicillium and genus Trichoderma seen to have parasitizing abilities and the genus Paecilomyces is thought to have antifungal antibiosis mechanism characterized by abnormality and melanisation in FOCe hyphae.

The average value of inhibition indicates a considerable number and it is suspected that isolates obtained from the rhizosphere are able to suppress the growth of pathogenic mushrooms. Strain
GNS.13.2a isolated from banana rhizosphere significantly reduced the density of native bacteria soon after inoculation, and Assays under axenic conditions or with soil microbiota showed antagonism by the native microbial community, with varying interactive or antagonistic effects [20]. In vitro biocontrol tests revealed that four Algerian isolates from rhizosphere of Trichoderma spp. (TAtC11, TGS7, TGS10, and TBS1) had a high antagonistic activity against Botrytis cinerea, the mycelial growth has been reduced by 62 to $65 \%$ in dual-culture technique [21]

\section{IV.CONCLUSION}

Based on the results of the study, it can be concluded that the mushroom rhizosphere isolated origin of shallot land Enrekang Regency have average percentage of inhibition as follow: 
1. The largest average value of inhibition is $74.79 \%$ in isolat number $16,73.19 \%$ in isolat number 5 and $63.16 \%$ in isolat number 6

2. The lowest inhibitory value is $1.56 \%$, isolat nomber 12

3. Inhibition values range $50-56 \%$, found in isolates nomber $3,7,9,13$ and 14

Mushroom rhizosphere isolated origin of shallot in Enrekang Regency can be suggested for antagonist agen which can suppress the growth of pathogenic mushroom Fusarium oxysporum, so that it can be developed as a location-specific biocontrol agent

\section{Acknowledgement}

Thank you to the Ministry of Technology BRIN. This research is a series research grant of Beginner Lecturer of the Ministry of Ristek BRIN funding 2021 above opportunity and funding, and thanks to the chair of the plants protection study program Hasanuddin University for facilitated laboratory and infrastructure and Laboran staff providing input, methods and technique. Thanks to the. Thank you to the Enrekang Regency agriculture office who has worked well together have provided data.

\section{REFERENCES}

[1]. BPS Kabupaten Enrekang, "Kabupaten Enrekang dalam Angka 2020,” p. 390, 2020.

[2]. H. Hikmahwati, Muhammad Rifqy Aulia, Ramlah, Fitrianti, "Identifikasi Cendawan Penyebab Penyakit Moler Pada Tanaman Bawang Merah ( Allium Ascolonicum L .) Di Kabupaten Enrekang," AGROVITAL J. Ilmu Pertan., vol. 5, no. November, pp. 83-86, 2020.

[3]. S. W. Prakoso, E.B.Prakoso and N. H., "Uji Ketahanan Berbagai Kultivar Bawang Merah ( Allium ascalonicum ) Terhadap Infeksi Penyakit Moler ( Fusarium oxysporum f . sp . cepae ) Endurance Test on Different Cultivars
Shallots ( Allium ascalonicum ) Against Infectious," Plumula, vol. 5, no. 1, 2016.

[4]. H. Hikmahwati, Muhammad Rifqy, Harli A Karim, Fitrianti, Nur Ilmi, "Karakterisasi morfologi cendawan penyebab antraknosa pada tanaman bawang merah (Allium ascolonicum L.) di kabupaten Enrekang," in PROSIDING SEMINAR NASIONAL BIOTEKNOLOGI 2020, 2020, no. 1, pp. 15-16.

[5]. H. Hekmawati, S. H. Poromarto, and S. Widono, "Resistensi Beberapa Varietas Bawang Merah Terhadap Colletotrichum Gloeosporioides," Agrosains J. Penelit. Agron., vol. 20, no. 2, p. 40, 2018, doi: 10.20961/agsjpa.v20i2.26342.

[6]. H. Nirwanto, Estimasi Kehilangan Hasil Ekonomi Produksi Bawang Merah terhadap Penyakit Bercak Ungu, Pertama. Surabaya: UPN Veteran Jawa Timur, 2011.

[7]. F. J. and B. A. S. Leslie, The Fusarium Laboratory Manual, First. USA: Blackwell publishing, 2006.

[8]. Y. H. Prabowo, F. Widiantini, and N. Istifadah, "Penyakit Busuk Pangkal (Fusarium oxysporum f.sp. cepae) pada Bawang Merah oleh Beberapa Jenis Bahan Organik," Agrikultura, vol. 31, no. 2, p. $145, \quad 2020, \quad$ doi: 10.24198/agrikultura.v31i2.28876.

[9]. M. Juwanda, K. Khotimah, and M. dan Amin, "Peningkatan Ketahanan Bawang Merah Terhadap Penyakit Layu Fusarium Melalui Induksi Ketahanan Dengan Asam Salisilat Secara Invitro,” Agrin, vol. 20, no. 1, pp. 15-28, 2016.

[10]. A. S. R. Suganda T., "Potensi jamur rizosfer bawang merah dalam menekan Fusarium oxysporum $f$. sp . cepae, penyebab penyakit busuk umbi bawang merah The potential of shallot rhizospheric fungi in suppressing Fusarium oxysporum $\mathrm{f}$. sp . cepae, the causal agent of basal rot di," J. Kultiv. Vol. 19 Maret 2020, vol. 19, no. 1, pp. 1015-1022, 2020. 
[11]. S. S. Kaeni Eni, Toekidjo, "Efektivitas Suhu dan Lama Perendaman Bibit Empat Kultivar Bawang Merah (Allium cepa L. Kelompok Aggregatum) pada Pertumbuhan dan Daya Tanggapnya terhadap Penyakit MOLER Effectiveness," Vegetalika, vol. 3, no. 1, pp. 5365, 2014.

[12]. T. V. Quyen, C. Hoang, T. Tin, and N. D. Khoa, "Disease-reducing effects of antagonistic soil bacteria on Fusarium basal rot of shallot caused by Fusarium oxysporum in Vĩnh Châu , Sóc Trăng," Can Tho Univ. J. Sci., vol. 6, pp. 31-37, 2017, doi: 10.22144/ctu.jen.2017.024.

[13]. Q. Xiong, J. Hu, H. Wei, H. Zhang, and J. Zhu, "Relationship between Plant Roots, Rhizosphere Microorganisms, and Nitrogen and Its Special Focus on Rice," pp. 1-18, 2021.

[14]. A. W. Nugroho, "Potensi Jamur Perakaran sebagai Agens Pengendalian Hayati Penyakit Moler ( Fusarium oxysporum f . sp . Cepae ) pada Bawang Merah Potential of RootColonizing Fungi as Biocontrol Agent of Moler Desease ( Fusarium oxysporum f . sp . Cepae ) on Shallot," Agrosains, vol. 17, no. 1, pp. 4-8, 2015, doi: https://doi.org/10.20961/agsjpa.v17i1.18656.

[15]. L. T. Xa and N. K. Nghia, "Antagonistic activity against plant pathogenic fungus by various indigenous microorganisms from different cropping systems in Soc Trang Province, Vietnam," Environ. Nat. Resour. J., vol. 18, no. 3, pp. 249-256, 2020, doi: 10.32526/ennrj.18.3.2020.23.

[16]. R. I. dan F. Karim A., "Isolasi dan Uji Antagonis Trichoderma terhadap Fusarium Oxysporum secara In vitro," Biosains, vol. 6 (1), 2020, doi: https://doi.org/10.24114/jbiov6i1.16839.

[17]. L. F. Izqu, A. Go, A. M. Co, and C. A. Mo, "Trichoderma virens G1006 and Bacillus velezensis Bs006: a compatible interaction controlling Fusarium wilt of cape gooseberry,"
Scintific Reports, vol. 10, no. 1, pp. 1-13, 2020, doi: 10.1038/s41598-020-63689-y.

[18]. S. K. dan R. R. Mukarlina, "Uji Antagonis Trichoderma harzianum terhadap Fusarium spp. Penyebab Penyakit Layu pada Tanaman Cabai ( Capsicum annum) secara In Vitro," Fitomedika, vol. 7(2), pp. 80-85, 2010.

[19]. T. Suganda, I. N. C. Simarmata, Y. Supriyadi, and E. Yulia, "Uji In-Vitro Kemampuan Ekstrak Metanol Bunga dan Daun Tanaman Kembang Telang (Clitoria ternatea L.) dalam Menghambat Pertumbuhan Jamur Fusarium oxysporum f.sp. cepae," Agrikultura, vol. 30, no. 3, p. 109, 2020, doi: 10.24198/agrikultura.v30i3.24031.

[20]. A. Ciancio, C. M. J. Pieterse, and J. Mercadoblanco, "Editorial: Harnessing Useful Rhizosphere Microorganisms for Pathogen and Pest Biocontrol," Front. Microbiol., vol. 7, no. October, pp. 1-5, 2016, doi: 10.3389/fmicb.2016.01620.

[21]. M. Hammad, T. Guillemette, M. Alem, F. Bastide, and M. Louanchi, "First report of three species of Trichoderma isolated from the rhizosphere in Algeria and the high antagonistic effect of Trichoderma brevicompactum to control grey mould disease of tomato," Egypt. J. Biol. Pest Control, vol. 4, 2021.

\section{Cite this article as :}

Hikmahwati, Fitrianti, Harli A. Karim, "Rhizosphere Mushrooms: Antagonistic Exploration of rhizospere mushrooms in Shallot (Allium ascolonicum L) specific location of Enrekang Regency", International Journal of Scientific Research in Science and Technology (IJSRST), Online ISSN : 2395-602X, Print ISSN : 23956011, Volume 8 Issue 6, pp. 428-433, NovemberDecember 2021. Available at doi : https://doi.org/10.32628/IJSRST218520 Journal URL : https://ijsrst.com/IJSRST218520 